\title{
RANCANG BANGUN SISTEM PENGELOLAAN DATA DAN PENYEDIAAN SUKU CADANG SEBAGAI PENUNJANG PRODUKSI
}

\author{
Rudy Yandri*1, Rosmawati ${ }^{2}$, Kurnia Damayanti ${ }^{3}$ \\ ${ }^{1}$ Program Studi Teknik Informatika Iniversitas Raharja, ${ }^{2}$ Dosen Sistem Informasi, \\ ${ }^{3)}$ Mahasiswa Program Studi Sistem Informasi. \\ email : rudy.yandri@ raharja.info ${ }^{1}$,rosmawati.dwi@ raharja.info ${ }^{2}$, \\ kurnia.damayanti@ raharja.info ${ }^{3}$
}

\begin{abstract}
Abstraksi
Proses pengelolaan data penyediaan suku cadang pada saat ini dibeberapa perusahaan masih kurang efektif, dikarenakan proses masih manual menggunakan buku besar untuk mengarsip data yang sudah di kelola, hal ini membutuhkan waktu yang lama sehingga tidak efisien. Untuk mengatasi permasalahan di atas, dibutuhkan suatu sistem yang terkomputerisasi sehingga bisa mengatasi permasalahan dan mempercepat proses. Oleh karena itu, penelitian ini mengusulkan rancangan sistem penyediaan suku cadang secara otomatis berdasarkan berbagai metode pengumpulan data, analisa menggunakan PIECES untuk mengevaluasi kinerja sistem dan rancangan yang meliputi UML (Unified Modeling Language) sebagai alat untuk membantu bahasa pemrograman berorientasi objek dan menggunakan MySQL sebagai database, yang pada akhirnya akan menghasilkan suatu sistem yang terintegrasi dengan baik. Sehingga dari penelitian ini bermanfaat untuk memudahkan proses mencapai target perusahaan dan mengefesiensikan sistem quality control pada mesin produksi.
\end{abstract}

Kata Kunci: Penyediaan suku cadang, Pengelolaan data, Penunjang produksi

\begin{abstract}
The process of managing spare parts supply data at this time in some companies is still ineffective, because the process is still manually using ledgers to archive data that has been managed, this requires a long time so it is not efficient. To overcome the above problems, a computerized system is needed so that it can overcome problems and speed up the process. Therefore, this study proposes the design of a system of providing spare parts automatically based on various methods of data collection, analysis using PIECES to evaluate system performance and design which includes UML (Unified Modeling Language) as a tool to help object-oriented programming languages and use MySQL as a database, which in the end will produce a system that is well integrated. So from this research it is useful to facilitate the process of achieving company targets and to streamline the quality control system on production machines
\end{abstract}

Keywords: Provision of spare parts, data management, production support.

\section{PENDAHULUAN}

Seiring dengan berkembangnya suatu perusahaan, pengelolaan terhadap informasi merupakan hal yang sangat penting. Informasi yang dikumpulkan dapat digunakan untuk membantu dalam mengelola, memperbaiki dan mengoptimalkan kinerja perusahaan, terutama pada perusahaan yang bergerak dibidang industri [1]. Dari perkembangan teknologi yang demikian pesat berdampak bagi seluruh kehidupan khususnya penyediaan informasi bagi suatu instansi atau perusahaan yang membutuhkan sistem pengelolaan data secara cepat, tepat dan akurat [3]. Untuk menunjang efektifitas, produktifitas dan efisiensi dalam suatu instanti atau 
perusahaan dalam menyelesaikan pekerjaan, memberikan pelayanan penyediaan suku cadang dengan tepat waktu dan sesuai target yang di rencanakan, maka perlu menyusun suatu sistem penyediaan suku cadang secara terkomputerisasi dengan baik dan berdaya guna. Sistem tersebut diharapkan dapat menyelesaikan tugas-tugas rutin yang berguna dalam pengambilan keputusan oleh instansi atau perusahaan, terutama pada penyediaan suku cadang sebagai penunjang produksi secara terkomputerisasi, yang bertujuan untuk menciptakan kinerja yang efektif dan efisien, karena lebih mudah mendapatkan informasi dan tidak perlu membuang banyak waktu. Pengelolaan informasi penyediaan suku cadang yang terkomputerisasi dapat meningkatkan produktivitas perusahaan dan memudahkan para karyawan dalam pengerjaannya [9].

Hasil pengamatan yang didapat bagian maintenance untuk melakukan penyediaan suku cadang belum ada sistem yang terkomputerisasi dan penyimpanan data masih manual atau berbentuk buku besar sehingga sulit untuk melakukan pencarian. Dari sisi keamanan data masih belum sepenuhnya optimal, sehingga pegawai yang tidak berwenang bisa membuka data dan merubah data. Serta dari sisi keakuratan data dan relevensi data masih belum terverifikasi dengan baik.

Suatu sistem yang terotomatisasi dapat membantu petugas dalam menyelesaikan kewajibanya dangan lebih cepat sehingga mengurangi tingkat keterlambatan yang akan mengganggu stabilitas perusahaan [5]. Persediaan barang merupakan barang-barang yang tersedia untuk dijual yaitu jika perusahaan itu berbentuk dagang dan juga bahan yang disimpan untuk digunakan dalam proses produksi. [2] Suku cadang atau Spare part adalah suatu alat yang mendukung pengadaan barang untuk keperluan peralatan yang digunakan dalam proses produksi . [4]

Sistem adalah suatu rangkaian yang terdiri dari dua atau lebih komponen yang saling berhubungan dan saling berinteraksi satu sama lain untuk mencapai tujuan dimana sistem biasanya terbagi dalam sub sistem yang lebih kecil yang mendukung sistem yang lebih besar. [8] Ketersediaan informasi yang cepat dan akurat serta didukung dengan penerapan sistem yang optimal menjadi kelebihan sendiri harus dimiliki setiap perusahaan. [10] Perancangan Sistem adalah suatu kegiatan membuat desain teknis berdasarkan kegiatan pada waktu proses analisis. Perancangan disini dimaksudkan suatu proses pemahaman dan peran suatu sistem informasi berbasis komputer. [11] Data adalah fakta dari hasil pengukuran atau pengamatan. Data dapat berupa huruf-huruf, angka, simbol-simbol khusus, atau gabungan darinya. [12]

\section{METODE PENELITIAN}

Metode penelitian merupakan suatu tata cara atau kegiatan pelaksanaan penelitian rangka untuk mengumpulkan informasi atau data serta melakukan investigasi terhadap data yang telah didapatkan tersebut. yang didasari oleh asumsi-asumsi dasar, pandangan-pandangan filosofis dan ideologis, pertanyaan dan isu-isu yang dihadapi [6][13]. Suatu penelitian mempunyai rancangan penelitian tertentu. Rancangan ini menggambarkan prosedur atau langkah-langkah yang harus ditempuh, waktu penelitian, sumber data dan kondisi arti untuk apa data dikumpulkan dan dengan cara bagaimana data tersebut dihimpun dan diolah untuk dianalisa dalam pembuatan laporan.

\section{Metode Observasi (Observasi Research)}

Pada tahapan ini penulis melakukan pengamatan langsung dari objek penelitian untuk mendapatkan data dan informasi yang akurat dan lengkap dari berbagai pihak yang terkait dan berhubungan dengan tema penelitian yang berhasil penulis rumuskan.

\section{a. Metode Wawancara (Interview Research)}

Penulis melakukan wawancara dengan bagian maintenance yang mengolah data suku cadang dan mesin produksi, penulis mendapatkan informasi berkaitan dengan penelitian penulis.

\section{b. Metode Studi Pustaka (Studi Literature)}


Selain melakukan observasi penulis juga melakukan data dengan cara studi pustaka, dalam metode ini penulis berusaha untuk melengkapi data-data yang diperoleh dengan membaca dan mempelajari dari buku-buku dan data-data yang relevan. Buku dan data tersebut digunakan penulis untuk membantu penganalisaan dan perancangan yang dilakukan.

\section{Metode Analisis Data}

Pada penelitian ini, metode analisa dilakukan dengan langkah-langkah melakukan pengamatan dan analisa terhadap sistem yang berjalan saat ini, serta menentukan UML (Unified Modeling Language) yang meliputi use case diagram, activity diagram, sequence diagram.

\section{HASIL DAN PEMBAHASAN}

Untuk dapat menggambarkan prosedur secara keseluruhan diperlukan bebrapa tahapan analisa sebagai bentuk pengumpulan informasi guna mendapatkan model yang sesuai dengan kebutuhan dan mampu memberikan solusi dengan cepat secara efektif dan efisien, mulai dari tahapan pengumpulan informasi dan kebutuhan, analisa dokumen, merancangan hubungan antar dokumen sampai dengan merancanga model diagram database dan model rancangan sistem [7]. Beberapa tahapan yang dimaksud sampai dengan model ranangan yang diciptakan dapat dilihat pada gambar $1,2,3,4,5$.

\section{Use Case Diagram Prosedur Berjalan}

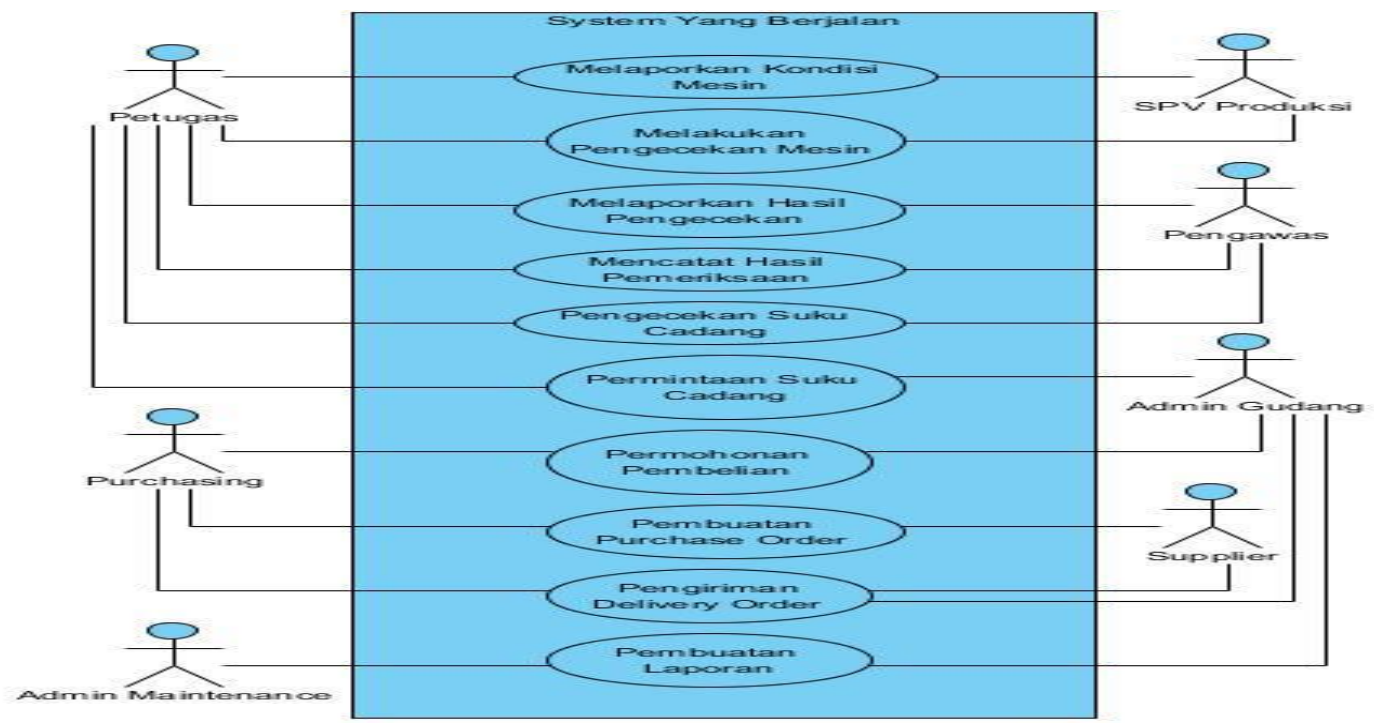

Gambar 1. Use Case Diagram

Berdasarkan gambar use case Diagram (gambar 1) yang berjalan saat ini sistem yang mencakup seluruh kegiatan pada sistem penyediaan suku cadang. Terdapat 7 (tujuh) Actor yang melakukan kegiatan yaitu spv produksi, petugas, pengawas, admin gudang, purchasing, supplier, admin maintenance yang berfungsi melaporkan kondisi mesin, mealakukan pengecekan mesin, melaporkan hasil pengecekan, mencatat hasil pemeriksaan, pengecekan suku cadang, permintaan suku cadang, permohonan pembelian, pembuatan purchase order, pengiriman delivery order, pembuatan laporan.

Terdapat juga 10 (sepuluh) use case yang merupakan proses yang terjadi pada sistem berjalan yaitu melaporkan kondisi mesin melibatkan petugas, melakukan pengecekan mesin melibatkan spv produksi, melaporkan hasil pengecekan dan mencatat hasil pemeriksaan ke pengawas, kemudian pengajuan permintaan suku cadang dari petugas ke admin gudang, selanjutnya permohonan pembeliaan yang diajukan oleh admin gudang ke purchasing, 
pelaksanaan pengiriman delivery order dilakukan oleh supplier ke purchasing kemudian seluruh dokumen pembuatan laporan akan di arsip oleh admin maintenance.

\section{Activity Diagram Prosedur Berjalan}

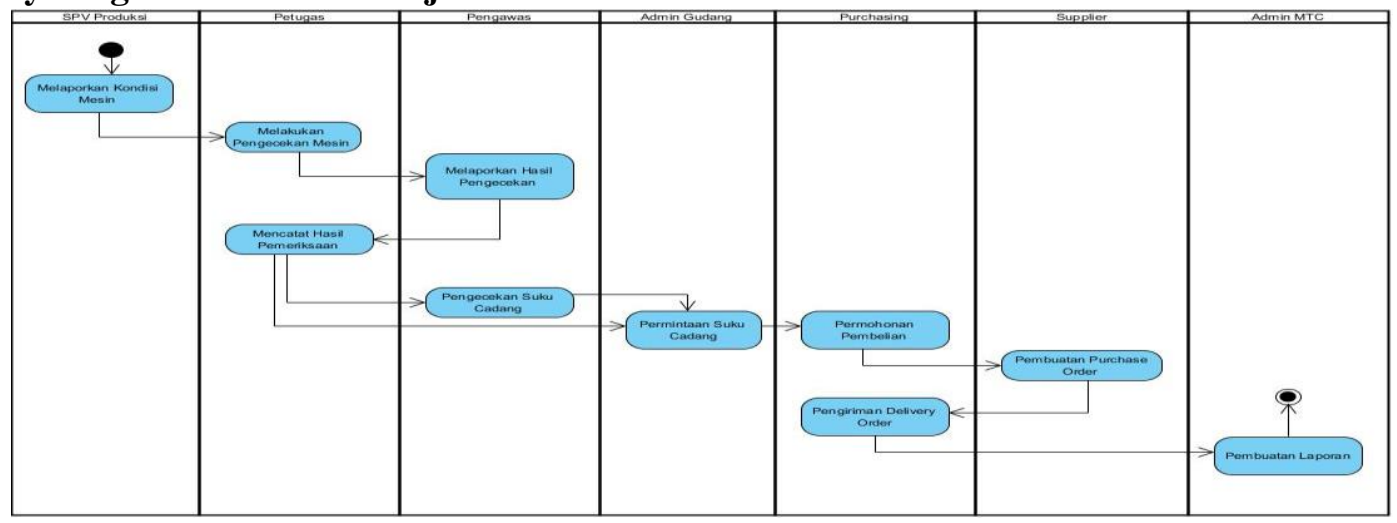

Gambar 2. Activity Diagram

Berdasarkan gambar activity diagram (gambar 2) yang berjalan saat ini sistem mencakup seluruh kegiatan penyediaan suku cadang. Sistem ini melibatkan 7 (tujuh) Actor yaitu, spv produksi yang melaporkan kondisi mesin, petugas melakukan pengecekan mesin dan mencatat hasil pemeriksaan, pengawas melaporkan hasil pengecekan dan pengecekan suku cadang, admin gudang melakukan permintaan suku cadang, purchasing melakukan permohonan pembelian dan pembuatan purchase order, supplier melakukan pengiriman delivery order, serta admin maintenance dalam pembuatan laporan.

\section{Squence Diagram Prosedur Berjalan}

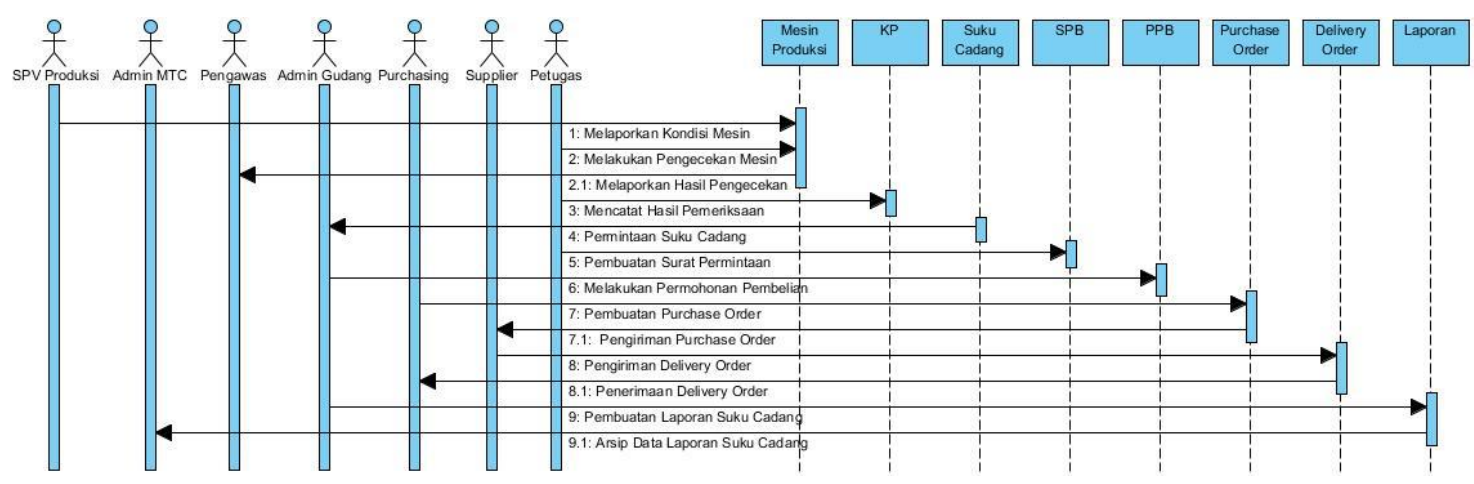

Gambar 3. Squence Diagram

Berdasarkan gambar sequence diagram (gambar 3) yang berjalan saat ini terlihat 3 (tiga) actor yang melakukan kegiatan diantaranya: staff admin finance, manager keuangan dan direktur utama, yang akan menyelesaikan 13 message spesifikasi dari komunikasi antar objek yang memuat informasi-informasi tentang aktifitas yang terjadi, yaitu melaporkan kondisi mesin, melakukan pengecekan mesin, melaporkan hasil pengecekan, mencatat hasil pemeriksaan, permintaan suku cadang, pembuatan surat permintaan, melakukan permohonan pembelian, pembuatan purchase order, pengiriman delivery order, penerimaan delivery order, pembuatan laporan suku cadang, dan arsip data laporan suku cadang.

Rancangan diatas (gambar 1, 2,3) merupakan gambaran prosedur yang berjalan dimana pada tahapan ini melibatkan beberapa dokumen kartu pemeriksaan. Dimana kartu pemeriksaan akan diisi oleh petugas dan admin maintenance yang akan menghasilkan surat permintaan, menjadi dasar pembuatan surat permohonan pembelian atau purchasing order sebagai tanda bukti pesanan yang telah dibuat dan telah ditanda tangani purchasing yang dikirim ke supplier. 
Surat jalan/delivery order yang dibuat oleh supplier yang befungsi sebagai bukti bahwa barang telah dikirim dan diterima oleh purchasing.

\section{Class Diagram}

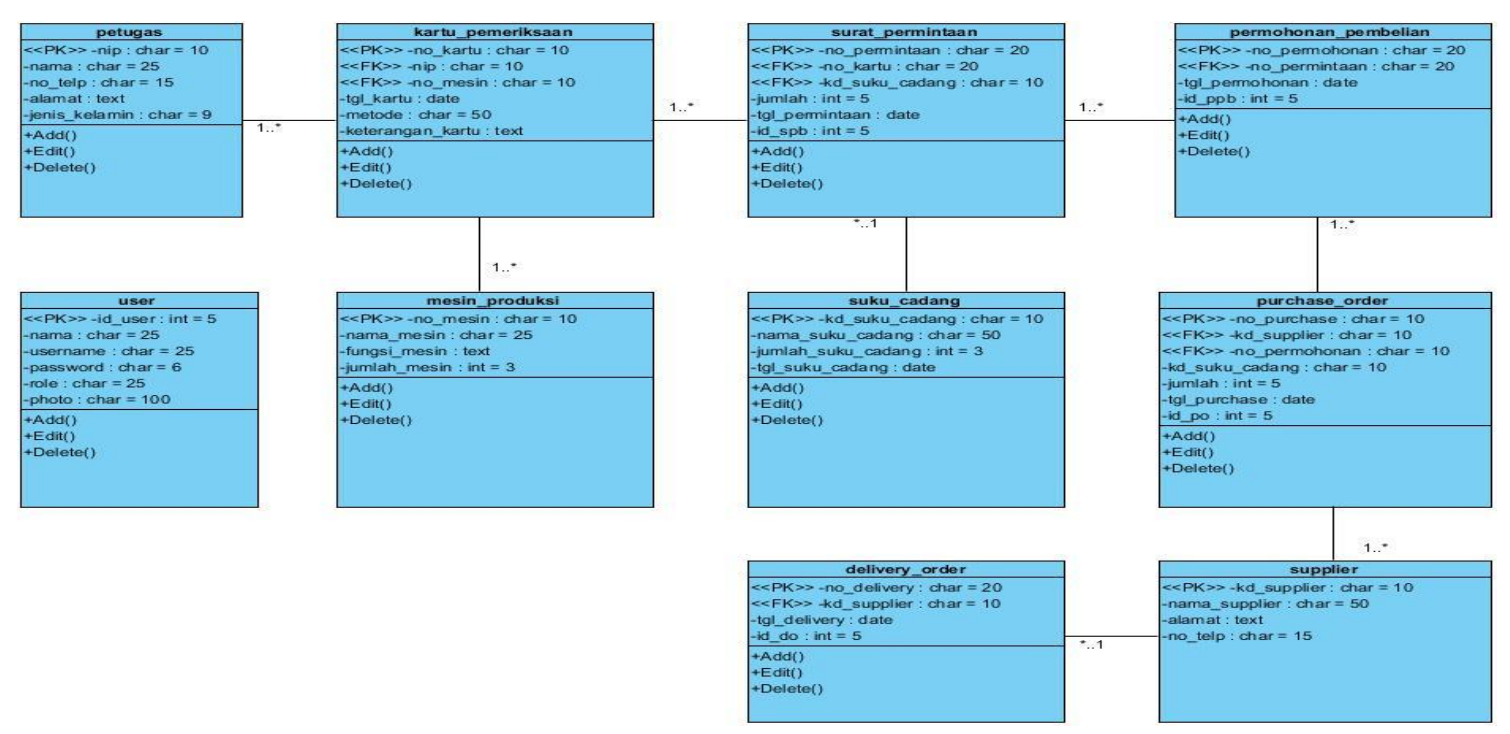

Gambar 4. Class Diagram

Berdasarkan gambar class diagram (gambar 4) yang berjalan saat ini sistem yang mencakup seluruh kegiatan pada sistem penyediaan suku cadang. Terdapat 10 (sepuluh) class yaitu petugas, mesin produksi, suku cadang, supplier yang merupakan tabel master, kartu pemeriksaan, surat permintaan, permohonan pembelian, purchase order, delivery order sebagai tabel transaksi, juga terdapat tabel user yang merupakan tabel akses untuk masuk ke dalam sistem.

Berdasarkan gambar class diagram (gambar 4) diatas dapat dilihat dengan jelas bahwa tingkat hubungan petugas dan kartu pemeriksaan yaitu one to many (1:M), tingkat hubungan mesin produksi dan kartu pemeriksaan yaitu one to many (1:M), ), tingkat hubungan kartu pemeriksaan dan surat permintaan yaitu one to many $(1: \mathrm{M})$, tingkat hubungan suku cadang dan surat permintaan yaitu one to many $(1: \mathrm{M})$, tingkat hubungan permohonan pembelian dan purchase order yaitu one to many (1:M), tingkat hubungan supplier dan permohonan pembelian yaitu one to many (1:M), tingkat hubungan supplier dan delivery order yaitu many to one (M:1), 


\section{Use Case Diagram Usulan}

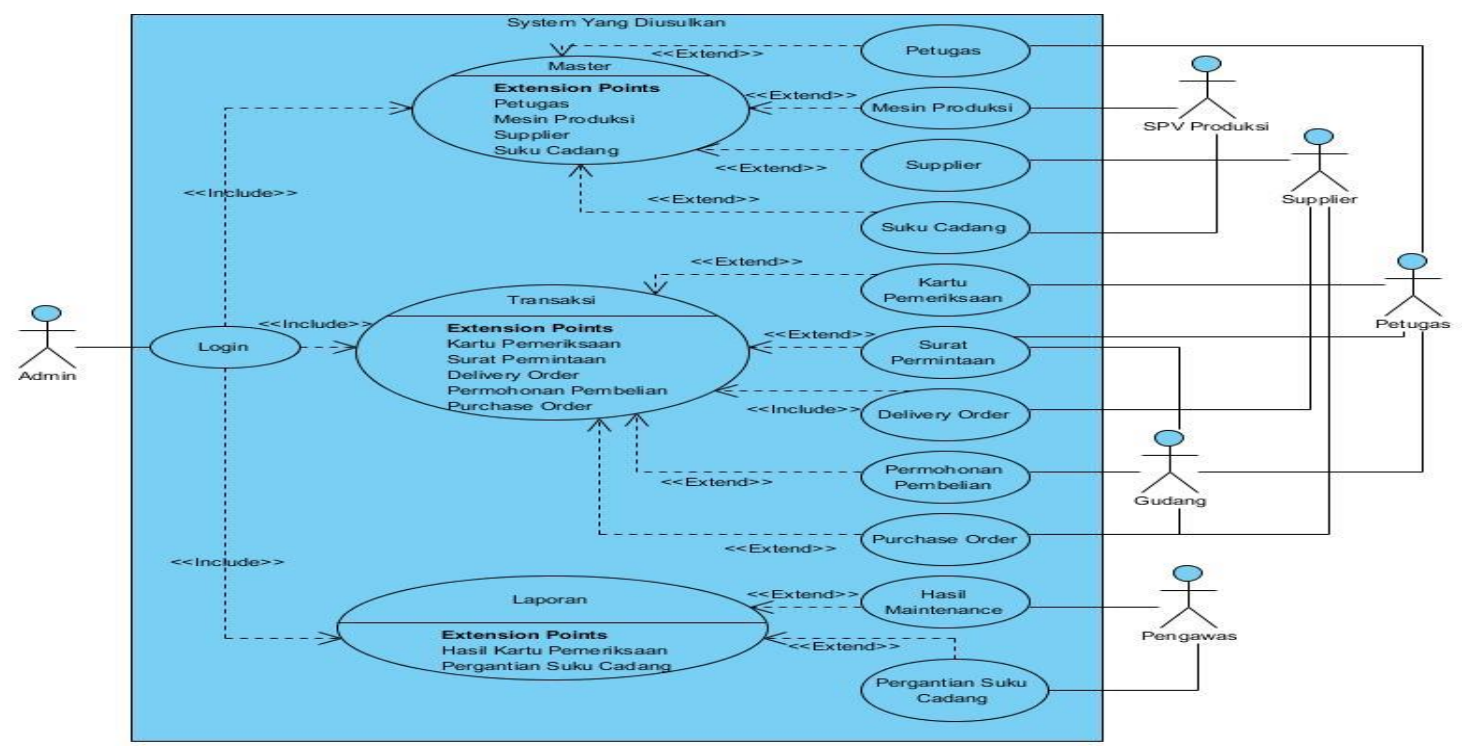

Gambar 5. Use Case Diagram

Berdasarkan gambar use case diagram usulan (gambar 5) terlihat jelas bahwa terdapat 15 (lima belas) use case yang terdiri dari 3 (tiga) use case utama yaitu master, transaksi, laporan. Use case master memiliki 4 (empat) yang terdiri dari petugas yang terhubung dengan aktor petugas, mesin produksi yang terhubung dengan aktor spv produksi, supplier terhubung dengan aktor supplier, suku cadang terhubung dengan spv produksi. Use case transaksi memiliki 5 (lima) yang terdiri dari kartu pemeriksaan, surat permintaan, permohonan pembelian, purchasing order, delivery order yang terhubung dengan aktor supplier, petugas dan admin gudang. Use case laporan memiliki 2 (dua) yang terdiri dari laporan hasil kartu pemeriksaan dan laporan pergantian suku cadang dengan aktor pengawas.

Use case diagram sebagai bentuk rancangan sistem yang akan diciptakan (gambar 5) merupakan desain model tampilan utama yang berorientasi pada kebutuhan menu aplikasi yang disiapkan, selain itu untuk kebutuhan penyimpanan informasi data agar dapat digunakan secara histori juga digambarkan dalam bentuk class diagram (gambar 4) lengkap dengan informasi field dan type data sesuai kebutuhan penyimpanan data. Serta use case login yang merupakan akses awal untuk masuk ke dalam sebuah sistem berdasarkan informasi data username dan password.

Untuk dapat menggamarkan bentuk basis data secara utuh, peneliti penggunakan aplikasi microsoft access sebagai bentuk gambaran dasar, dan pada akhirnya bentuk rancangan basis data ini dapat disesuaikan menggunakan apa saja sesuai kebutuhan.

a. Tabel Master: User

Primary Key : id_user

Foreign Key : : -

Structure Tabel $\quad: \quad\{$ id_user, nama, username, password, role, photo $\}$

\begin{tabular}{|c|c|c|c|c|c|c|c|}
\hline & \# & Nama & Jenis & Penyortiran Atribut & Kosong & Bawaan & Ekstra \\
\hline$\square$ & 1 & id_user & $\operatorname{int}(5)$ & & Tidak & Tidak ada & AUTO_INCREMENT \\
\hline$\square$ & 2 & nama & varchar(30) & & Tidak & Tidak ada & \\
\hline$\square$ & 3 & username & varchar(30) & & Tidak & Tidak ada & \\
\hline$\square$ & 4 & password & varchar(20) & & Tidak & Tidak ada & \\
\hline$\square$ & 5 & role & varchar(20) & & Tidak & Tidak ada & \\
\hline$\square$ & 6 & photo & varchar(100) & & Tidak & Tidak ada & \\
\hline
\end{tabular}




\section{b. Tabel Master: Petugas}

Primary Key : nip

Foreign Key : $\quad$ -

Structure Tabel $\quad: \quad\{$ nip, nama, no_telp, alamat, jenis_kelamin \}

\begin{tabular}{|c|c|c|c|c|c|c|}
\hline & \# & Nama & Jenis & Penyortiran & Kasong & Bawaan \\
\hline$\square$ & 1 & nip $\infty$ & char(10) & & Tidak & Tidak ada \\
\hline$\square$ & 2 & nama & char(25) & & Ya & NULL \\
\hline$\square$ & 3 & no_telp & char (15) & & Ya & NULL \\
\hline$\square$ & 4 & alamat & text & & Ya & NULL \\
\hline$\square$ & 5 & jenis_kelamin & char(9) & & Ya & NULE \\
\hline
\end{tabular}

Tabel 2. Struktur Petugas

c. Tabel Master: Mesin Produksi

Primary Key : no_mesin

Foreign Key : -

Structure Tabel $\quad$ : no_mesin, nama_mesin, fungsi_mesin, jumlah_mesin $\}$

\begin{tabular}{|c|c|c|c|c|c|c|c|}
\hline & \# & Nama & Jenis & Penyortiran Atribut & Kosong & Bawaan & Ekstra \\
\hline$\square$ & 1 & no_mesin & char(5) & & Tidak & Tidak ada & \\
\hline$\square$ & 2 & nama_mesin & $\operatorname{char}(25)$ & & Ya & NULL & \\
\hline$\square$ & 3 & fungsi_mesin & text & & Ya & NULL & \\
\hline$\square$ & 4 & jumlah_mesin & $\operatorname{int}(3)$ & & Ya & NULL & \\
\hline
\end{tabular}

Tabel 3. Stuktur Mesin Produksi

d. Tabel Master: Suku Cadang

Primary Key : $\quad$ kd_suku_cadang

Foreign Key : -

Structure Tabel : \{kd_suku_cadang, nama_suku_cadang, jumlah_suku_cadang, tgl_suku_cadang \}

\begin{tabular}{|c|c|c|c|c|c|c|c|c|}
\hline & $\#$ & Nama & Jenis & Penyortiran & Atribut & Kosong & Bawaan & Ekstra \\
\hline$\square$ & 1 & kd_suku_cadang & $\operatorname{char}(10)$ & & & Tidak & Tidak ada & \\
\hline$\square$ & 2 & nama_suku_cadang & char(50) & & & Ya & NULL & \\
\hline$\square$ & 3 & jumlah_suku_cadang & $\operatorname{int}(3)$ & & & Ya & $N U L L$ & \\
\hline$\square$ & 4 & tgl_suku_cadang & date & & & Ya & NULL & \\
\hline
\end{tabular}

Tabel 4. Struktur Suku Cadang

e. Tabel Master: Supplier

Primary Key : kd_supplier

Foreign Key : -

Structure Tabel : $\{$ kd_supplier, nama_supplier, alamat, no_telp \}

\begin{tabular}{|c|c|c|c|c|c|c|c|c|}
\hline & \# & Nama & Jenis & Penyortiran & Atribut & Kosong & Bawaan & Ekstra \\
\hline$\square$ & 1 & kd_supplier $\gg$ & char(10) & & & Tidak & Tidak ada & \\
\hline$\square$ & 2 & nama_supplier & char $(50)$ & & & Ya & NULL & \\
\hline$\square$ & 3 & alamat & text & & & Ya & NULL & \\
\hline$\square$ & 4 & no_telp & char(15) & & & Ya & NULL & \\
\hline
\end{tabular}

Tahel 5. Struktur Sunnlier 


\section{f. Tabel Transaksi: Kartu Pemeriksaan (KP)}

Primary Key : no_kartu

Foreign Key $\quad: \quad\{$ nip, no_mesin $\}$

Structure Tabel : \{no_kartu, nip, no_mesin,tgl_kartu, metode, keterangan_kartu \}

\begin{tabular}{|llllll}
\hline$\square$ & Nama & Jenis & Penyortiran Atribut & Kosong & Bawaan Ekstra \\
1 & no_kartu & Char(10) & Tidak & Tidakada \\
2 & nip & char(10) & Ya & NULL \\
3 & no_mesin & char(5) & Ya & NULL \\
4 & tgl_kartu & date & Ya & NULL \\
5 & metode & char(50) & Ya & NULL \\
\hline & 6 & keterangan_kartu text & Ya & NULL
\end{tabular}

Tabel 6. Struktur Kartu Pemeriksaan

g. Tabel Transaksi: Surat Permintaan (SPB)

Primary Key : no_permintaan

Foreign Key $\quad: \quad\{$ no_kartu, kd_suku_cadang $\}$

Structure Tabel : \{ no_permintaan, no_kartu, kd_suku_cadang, jumlah, tgl_permintaan, id_spb \}

\begin{tabular}{|c|c|c|c|c|c|c|c|}
\hline & $\#$ & Nama & Jenis & Penyortiran Atribut & Kosong & Bawaan & Ekstra \\
\hline$\square$ & 1 & no_permintaan & char(20) & & Tidak & Tidak ada & \\
\hline$\square$ & 2 & no_kartu & char(10) & & Ya & NULL & \\
\hline$\square$ & 3 & kd_suku_cadang & char(10) & & Tidak & Tidak ada & \\
\hline$\square$ & 4 & jumlah & $\operatorname{int}(5)$ & & Tidak & Tidak ada & \\
\hline$\square$ & 5 & tgl_permintaan & date & & Ya & NULL & \\
\hline$\square$ & 6 & id_spb@ & $\operatorname{int}(5)$ & & Tidak & Tidak ada & AUTO_INCREMENT \\
\hline
\end{tabular}

Tabel 7. Struktur Surat Permintaan

h. Tabel Transaksi: Permohonan Pembelian (PPB)

Primary Key : no_permohonan

Foreign Key : \{no_permintaan \}

Structure Tabel : \{no_permohonan, no_permintaan, tgl_permohonan, id_ppb \}

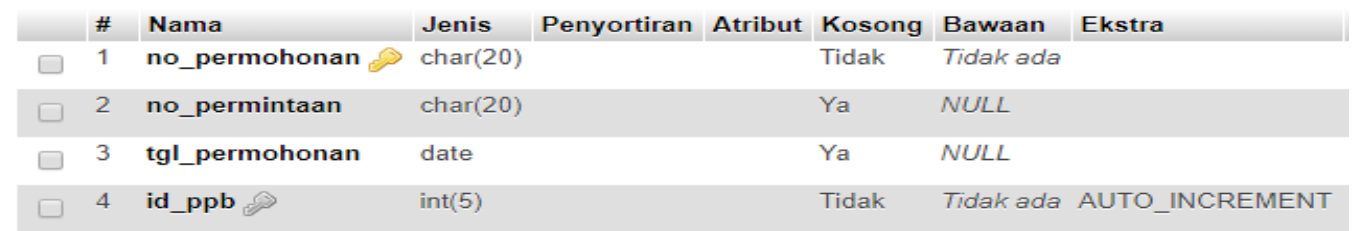

Tabel 8. Struktur Permohonan Pembelian

i. Tabel Transaksi: Purchase Order (PO)

Primary Key : no_purchase

Foreign Key $\quad: \quad\{$ kd_supplier, no_permohonan $\}$

Structure Tabel : $\{$ no_purchase, kd_supplier, kd_suku_cadang, jumlah, no_permohonan, tgl_purchase, id_po \}

\begin{tabular}{|c|c|c|c|c|c|c|c|}
\hline & \# & Nama & Jenis & Penyortiran Atribut & Kosong & Bawaan & Ekstra \\
\hline$\square$ & 1 & no_purchase & $\operatorname{char}(20)$ & & Tidak & Tidak ada & \\
\hline$\square$ & 2 & kd_supplier & char(10) & & Ya & NULL & \\
\hline$\square$ & 3 & kd_suku_cadang & char(10) & & Tidak & Tidak ada & \\
\hline$\square$ & 4 & jumlah & $\operatorname{int}(5)$ & & Tidak & Tidak ada & \\
\hline$\square$ & 5 & no_permohonan & $\operatorname{char}(20)$ & & Ya & NULL & \\
\hline$\square$ & 6 & tgl_purchase & date & & Ya & NULL & \\
\hline$\square$ & 7 & id_po & $\operatorname{int}(5)$ & & Tidak & Tidak ada & AUTO_INCREMENT \\
\hline
\end{tabular}

Tabel 9. Struktur Purchase Order

j. Tabel Transaksi: Delivery Order (DO)

Primary Key : no_delivery

Foreign Key $\quad: \quad\{$ kd_supplier $\}$ 
Structure Tabel : \{id_do, no_delivery, tgl_delivery, kd_supplier $\}$

\begin{tabular}{|c|c|c|c|c|c|c|c|c|}
\hline & \# & Nama & Jenis & Penyortiran & Atribut & Kosong & Bawaan & Ekstra \\
\hline$\square$ & 1 & id_do? & $\operatorname{int}(5)$ & & & Tidak & Tidak ada & AUTO_INCREMENT \\
\hline$\square$ & 2 & no_delivery & char(20) & & & Tidak & Tidak ada & \\
\hline$\square$ & 3 & tgl_delivery & date & & & Ya & NULL & \\
\hline$\square$ & 4 & kd_supplier & char(10) & & & Tidak & Tidak ada & \\
\hline
\end{tabular}

Tabel 10. Struktur Deliverv Order

\section{Grafik Monitoring Pergantian Suku Cadang}

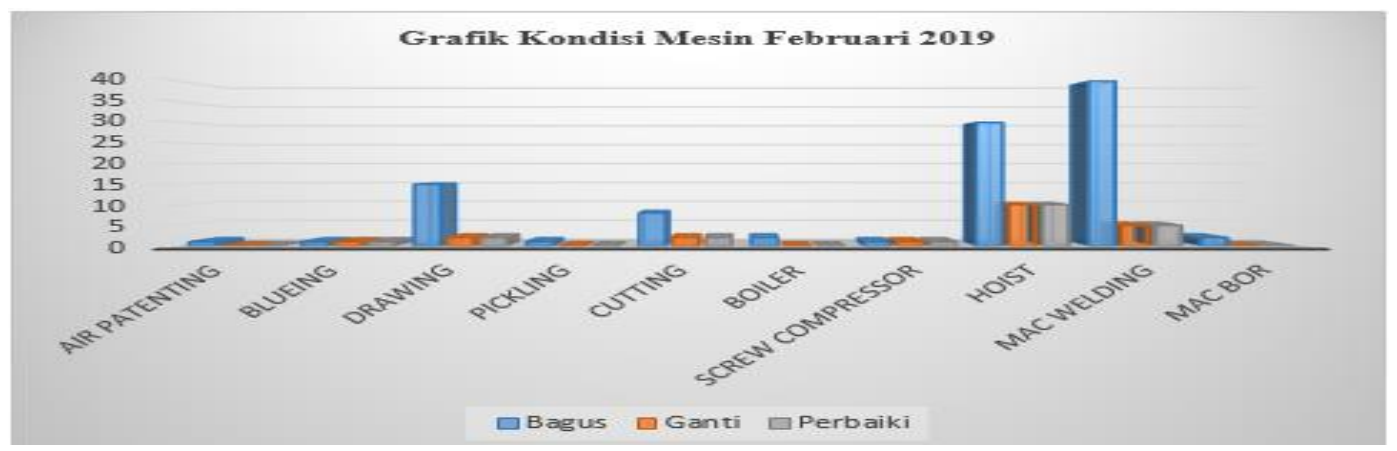

Gambar 6. Grafik Kondisi Mesin Februari 2019

Grafik diatas (gambar 6) merupakan grafik monitoring pembayaran suplier berdasarkan waktu (bulan). Hal ini bisa membantu manajemen dalam menunjang keputusan guna pembayaran mana yang menjadi prioritas pembayaran. Grafik diatas bisa diambil berdasarkan Datewarehouse, sebagaimana di definisikan "Doing Data Warehouse (DW) to your business or system is not only think about the trend only, but how to understand the DW knowledge itself and how to implement it" [14]. Dan bagaimana cara mengukurnya "Measures are a standard unit used to express the size, amount, or degree of something, qualities are often difficult to be measured as it needs to have some certain parameter or elements, and those parameters must be quantifiable and verifiable" [15]

\section{Diagram HIPO}

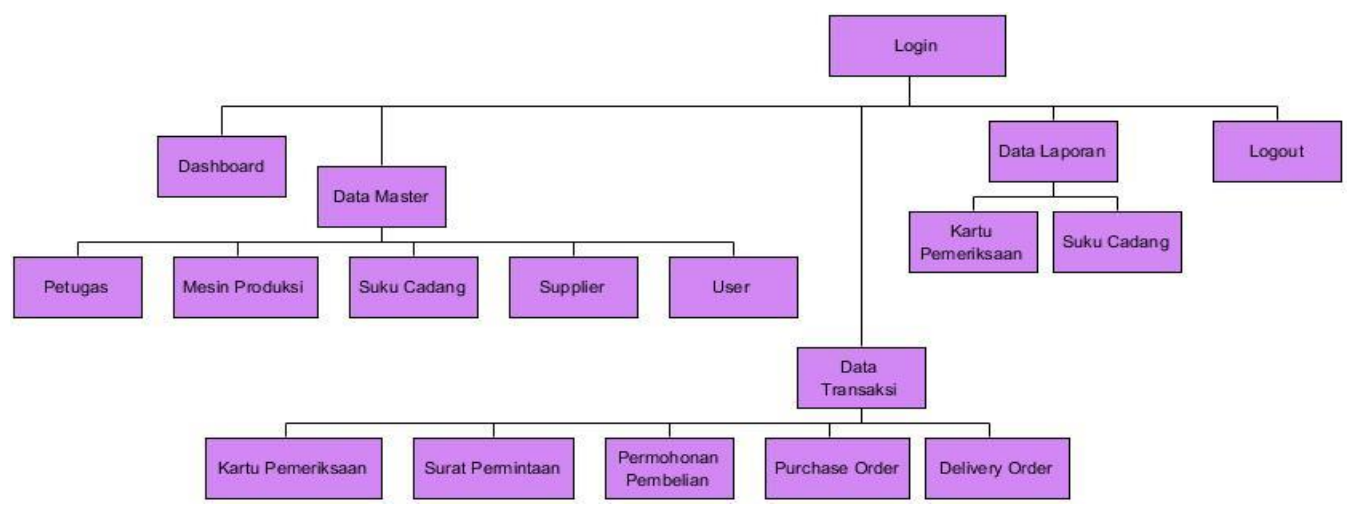

Gambar 7. Diagram HIPO

Untuk menggambarkan stuktur menu dari sistem yang dirancang dapat digambarkan dengan diagram HIPO (Hierarchy Input Process Output). Untuk menyediakan suatu struktur guna memahami fungsi-fungsi dari program. Terlihat dari diagram HIPO diatas (gambar 7) terdapat 1 (satu) fungsi utama yaitu login (digram 0) dan 5 (lima) fungsi dibawahnya, yaitu fungsi menu dashboard (diagram 1), menu data master (diagram 2), menu data transaksi (diagram 3), menu data laporan (diagram 4) dan menu logout (diagram 5). Didalam fungsi menu 
data master (diagram 2) terdapat 5 (lima) fungsi sub menu yaitu menu petugas (diagram 2.1), menu mesin produksi (diagram 2.2), menu suku cadang (diagram 2.3), menu supplier (diagram 2.4), dan menu user (diagram 2.5). Didalam fungsi menu data transaksi (diagram 3) terdapat 5 (lima) fungsi sub menu yaitu menu kartu pemeriksaan (diagram 3.1), menu surat permintaan (diagram 3.2), menu permohonan pembelian (diagram 3.3), menu purchase order (diagram 3.4), dan delivery order (diagram 2.5). Didalam fungsi menu laporan (diagram 4) terdapat 2 (dua) fungsi sub menu yaitu menu laporan kartu pemeriksaan (diagram 4.1), dan menu laporan suku cadang (4.2).

\section{Rancangan Tampilan}

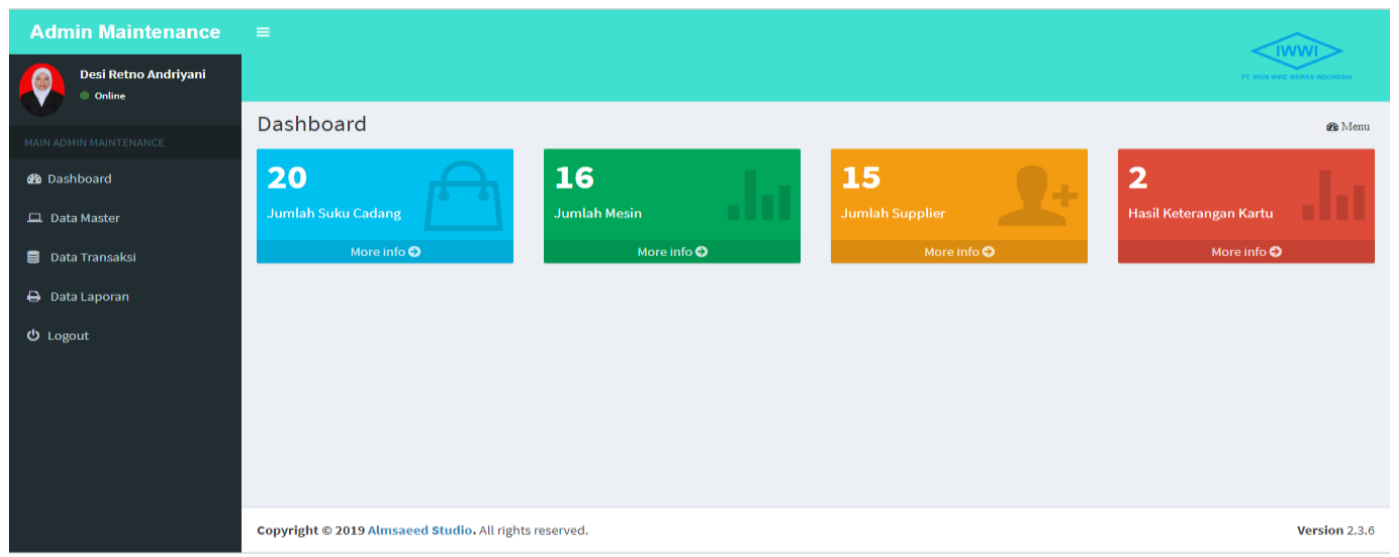

Gambar 8. Tampilan Dashboard

Terlihat pada tampilan layar diatas (gambar 8) merupakan tampilan layar utama yang terdiri dari menu master, menu transaksi dan menu report.

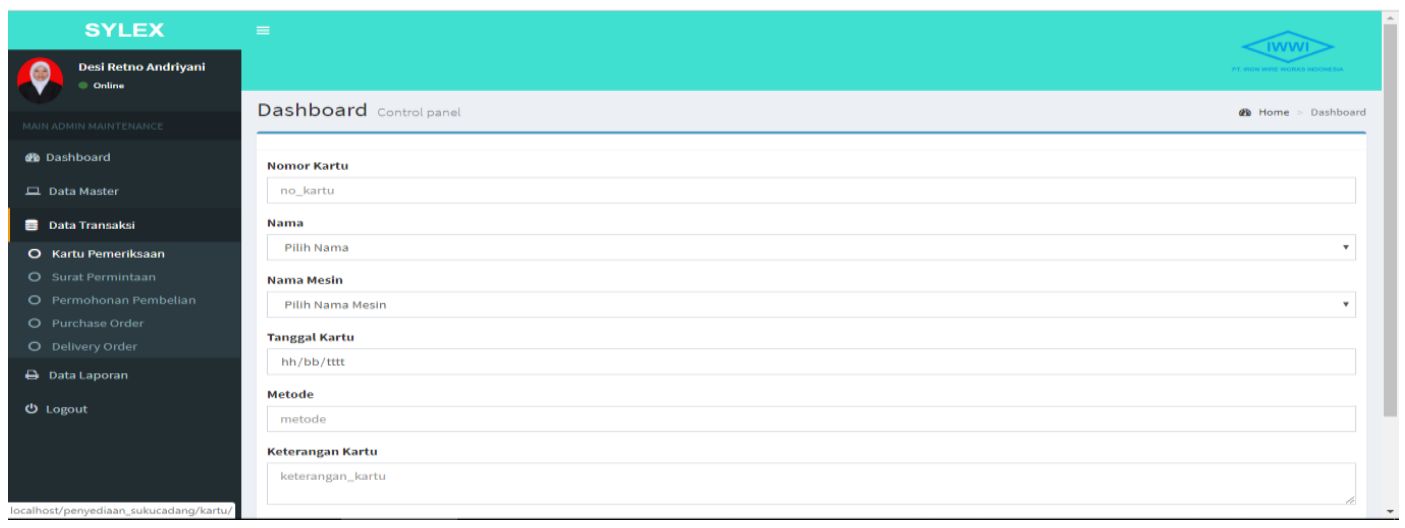

Gambar 9. Tampilan Menu Input Kartu Pemeriksaan

Terlihat pada tampilan layar diatas (gambar 9) merupakan tampilan layar utama yang terdiri dari menu master, menu transaksi dan menu report, dimana menu transaksi memiliki sub menu surat jalan, sub menu invoice dan sub menu tanda terima invoice. 


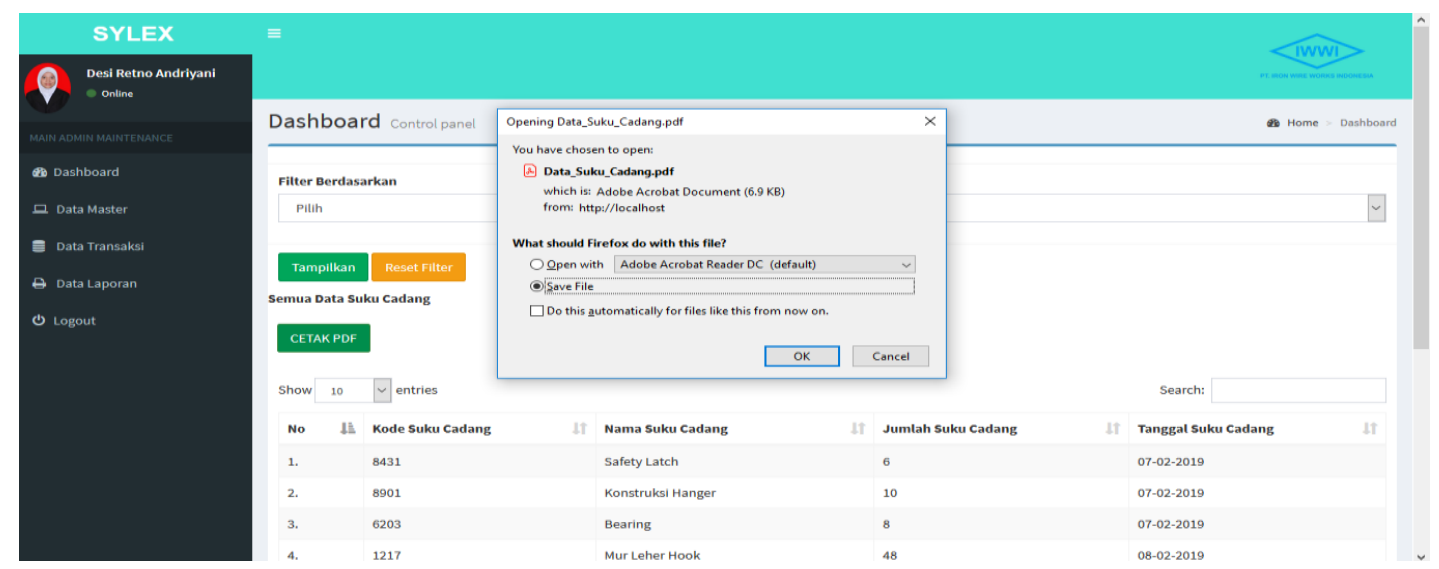

Gambar 10. Tampilan Cetak Laporan PDF

Terlihat pada tampilan layar diatas (gambar 10) merupakan tampilan layar utama yang terdiri dari menu master, menu transaksi dan menu report, dimana menu report memiliki sub menu tagihan hutang supplier, jatuh tempo hutang, presentasi jatuh tempo dan estimasi pembayaran.

\section{Query Penciptaan Informasi}

\section{Query Function Tambah Aksi:}

function tambah_aksi ()\{

\$nip $=$ \$this->input->post('nip');

\$conn = mysqli_connect('localhost','root',",'penyediaan_sukucadang');

mysqli_select_db(\$conn,'petugas');

\$cek $=$ mysqli_num_rows $($ mysqli_query $($ \$conn, ,SELECT $*$ FROM petugas WHERE

nip='\$nip'"));

if $(\$ c e k>0)\{$

echo "<script>window.alert('nip yang anda masukan sudah ada')

window.location='http://localhost/penyediaan_sukucadang/petugas/tambah' $</$ script $>$ ";

\}

\$nama $=$ \$this->input->post('nama');

\$no_telp $=$ \$this->input->post('no_telp');

\$alamat $=$ \$this- $>$ input $->$ post('alamat');

\$jenis_kelamin $=\$$ this->input->post('jenis_kelamin');

$\$$ data $=\operatorname{array}($

'nip' => \$nip,

'nama' => \$nama,

'no_telp' => \$no_telp,

'alamat' $=>$ \$alamat,

'jenis_kelamin' => \$jenis_kelamin

);

\$this->m_petugas->input_data(\$data,'petugas');

\$this->session->set_flashdata('msg','data berhasil di simpan');

redirect('petugas/index'); \}

\section{Query Function Edit:}

function edit(\$id)\{

\$where = array('id_do' => \$id);

\$data['delivery'] = \$this->m_delivery->edit_data(\$where,'delivery_order')->result();

\$this->load->view('header'); 
\$this->load->view('edit_delivery',\$data);

\$this->load->view('footer'); \}

\section{Query Function Update:}

function update ()\{

\$id_do $=$ \$this->input->post('id_do');

\$no_delivery $=$ \$this->input->post('no_delivery');

$\$$ conn = mysqli_connect('localhost','root',",'penyediaan_sukucadang');

mysqli_select_db(\$conn,'delivery_order');

\$cek = mysqli_num_rows $($ mysqli_query $(\$ c o n n, " S E L E C T *$ FROM delivery_order

WHERE no_delivery='\$no_delivery'"));

if $(\$ c e k>0)\{$

echo "<script>window.alert('no delivery yang anda masukan sudah ada')

window.location='http://localhost/penyediaan_sukucadang/delivery/update'</script $>$ "; \}

\section{KESIMPULAN}

Berdasarkan hasil analisa dan penelitian yang dilakukan, maka penulis menyimpulkan bahwa proses penyediaan suku cadang saat ini masih manual, sehingga menyebabkan proses menjadi tidak efektif dan efisien. Hal ini terlihat dari lamanya waktu yang dibutuhkan, mulai dari proses penginputan data sampai dengan pembuatan laporan penyediaan suku cadang, selain itu juga menyebabkan tingkat keakuratan yang rendah, karena masih terdapat beberapa kesalahan. Untuk mengatasi permasalahan diatas, sistem yang diusulkan mampu berjalan secara terkomputerisasi sehingga membuat proses penyediaan suku cadang menjadi efektif dan efisien, selain itu juga mampu menciptakan laporan hasil kartu pemeriksaan dan laporan pergantian suku cadang dengan cepat dan akurat menggunakan beberapa metode analisa dan perancangan yang penulis lakukan

\section{DAFTAR PUSTAKA}

[1] Junaidi, J., Roji, A., \& Munawar, K. (2015). Konsep Otomatisasi Sistem Pembayaran SPP Online Untuk Mengurangi Tingkat Keterlambatan. Proceedings Konferensi Nasional Sistem dan Informatika (KNS\&I)..

[2] Reeve. Waren, Fees. 2015. Accounting (Pengantar Akuntansi).Jakarta : Salemba Empat.

[3] Junaidi, T. K. Y. N. D. (2013). Sistem Pakar Monitoring Inventory Control Untuk Menghitung Harga Jual Efektif Dalam Meningkatkan Keuntungan. Yogyakarta: Universitas Ahmad Dahlan.

[4] Prawira, Ilham. "Sistem informasi persediaan suku cadang barang berbasis web pada bengkel mobil auto rizal palembang". Diss.UIN Raden Fatah Palembang, 2017.

[5] Junaidi, J., Effendy, M. Y., \& Hartono, H. (2015). REKAYASA MODEL APLIKASI SISTEM PRODUCT KNOWLADGE UNTUK MENDUKUNG PENGAMBILAN KEPUTUSAN DALAM MENENTUKAN KINERJA KARYAWAN. CERITA Journal, 1(1), 46-55.

[6] Henderi, H., Junaidi, J., \& Kusuma, T. A. H. (2012). Dashboard Monitoring System Penjualan Dan Reward Mobile Kios PT. Telekomunikasi Seluler. Semantik, 2(1).. 
[7] Junaidi, J., Arifin, R., \& Septiani, A. (2015). Rancang Bangun Aplikasi Sistem Inventory Berbasis Desktop Menggunakan JSE. Proceedings Konferensi Nasional Sistem dan Informatika (KNS\&I)..

[8] Soleh, Oleh dkk. 2018. Aplikasi Monitoring Jumlah Bibit Tanaman Menggunakan Analisa Balance Score Card pada UPTD TPA Rawa Kucing Kota Tangerang. Jurnal Semnasteknomedia Vol.6 No.1 Hal: 128-132.

[9] Junaidi, J., Setianingsih, R., \& Khotimah, K. (2015). Rancang Bangun Sistem Penerimaan Dan Pengeluaran Barang Menggunakan Java Aplikasi. Proceedings Konferensi Nasional Sistem dan Informatika (KNS\&I)..

[10] Permana, Handy Januar, Erna Astriyani, and Tanti Mayang Sari. "PERANCANGAN SISTEM INFORMASI MANAJEMEN LAYOUT BAHAN BAKU BERBASIS WEB PADA PT. SANICHEM TUNGGAL PERTIWI." SENSI Journal 4.2 (2018): 205-219.

[11] Junaidi, J., Santoso, S., \& Sunarya, L. (2008). Rekayasa Teknik Pemrograman Pencegahan Dan Perlindungan Dari Virus Lokal Menggunakan API Visual Basic. CCIT Journal, 1(2), 134-153..

[12] Martono, A., \& Junaidi, D. Y. IMULATION GAME BASED ON JARIMAGIC METHOD TO CALCULATE MORE QUICKLY FOR ELEMENTARY STUDENTS.

[13] Junaidi, J., Cholisoh, N., \& Hasanah, N. (2018). Rancang Bangun Sistem Manajemen Aset IT Untuk Pencatatan History Maintenance Sebagai Pendukung Keputusan. SENSI Journal, 4(2), 220-231..

[14] M. Subekti, Warnars Junaidi, H.L.H.S., Y. Heryadi, "The 3 steps of best data warehouse model design with leaning implementation for sales transaction in franchise restaurant", Cybernetics and Computational Intelligence (CyberneticsCom) 2017 IEEE International Conference on, 20-22 Nov 2017.

[15] J. Junaidi, A. Julianto, N. Anwar, S. Safrizal, H.L.H.S. Warnars, K. Hashimoto, "Perfecting a Video Game with Game Metrics", Telkomnika, vol. 16, no. 3, pp. 13241331, June 2018 